\title{
Exploring the role of SYK in respiratory in vivo models
}

Michael Caniga', Janice D Woodhouse ${ }^{1}$, Alan Wilhelm", Malgorzata A Gil ${ }^{1}$, Yanlin Jia ${ }^{1}$, Hongshi Yu' ${ }^{1}$, Stella Vincent ${ }^{1}$, Richard Millerr', Gissela Lieber ${ }^{2}$, Xiomara Fernandez², Richard Chapman², Robbie McLeod', Lily Y Moy', Nancy Kelly ${ }^{1}$, Emily Hickey ${ }^{2}$, Michael A Crackower ${ }^{1}$, Thomas Miller ${ }^{1}$, William M Abraham ${ }^{3}$, Milenko Cicmil ${ }^{*}$

From 2nd Cross Company Respiratory Symposium

Horsham, UK. 6-7 September 2012

\section{Background}

Spleen Tyrosine Kinase (SYK) is a key activator of signaling pathways downstream of multiple surface receptors implicated in asthma. SYK function has been extensively studied in Last cells downstream of the high-affinity IgE receptor (FceR1). Most studies evaluating SYK function in preclinical models have relied on poorly selective compounds, anti-sense oligonucleotides, or SYK knockout mice. Here we describe the characterization of SYK mechanism in multiple in vivo model settings.

\section{Materials and methods}

The effect of SYK inhibitor MRK-A on allergic airway responses was evaluated in IgE-mediated tracheal extravasation in rat, Brown Norway Ova rat models of allergic inflammation and the sheep inhaled ascaris allergen challenge model.

\section{Results}

MRK-A dose-dependently blocked IgE-mediated tracheal extravasation in rat. In a Brown Norway rat ovalbuminsensitized airway challenge model oral dosing of MRK-A led to a dose-dependent inhibition of airway inflammation. Intravenous dosing of MRK-A was able to significantly inhibit both early and late allergen- induced changes in airway resistance in an ascaris-sensitive sheep allergen challenge model as well as airway hyper responsiveness.

\section{Conclusions}

Here we demonstrated that SYK mechanism plays a significant role in several in vivo allergen challenge models. This ranges from simple PK/PD mast cells driven models

Merck Research Laboratories, Boston, MA 02115, USA such as the IgE-mediated tracheal extravasation to the more complex and clinically relevant sheep inhaled allergen challenge model.

\section{Authors' details}

${ }^{1}$ Merck Research Laboratories, Boston, MA 02115, USA. ${ }^{2}$ Merck Research Laboratories, Kenilworth, NJ 07033, USA. ${ }^{3}$ Mount Sinai Medical Center, Miami Beach, FL 33140, USA.

Published: 14 August 2013
Submit your next manuscript to BioMed Central and take full advantage of:

- Convenient online submission

- Thorough peer review

- No space constraints or color figure charges

- Immediate publication on acceptance

- Inclusion in PubMed, CAS, Scopus and Google Scholar

- Research which is freely available for redistribution
( Bïomed Central
Full list of author information is available at the end of the article

C Biomed Central 